\title{
Use of Information and Communication Technology in Enhancing Teaching and Learning
}

\author{
Siti Maliza Hj Salleh \\ Faculty of Accountancy, Universiti Teknologi MARA Sarawak, Kota Samarahan Campus \\ Jalan Meranek, 94300 Kota Samarahan, Sarawak. Malaysia \\ Tel: 60-198-869-461Ｅ-mail: sitimaliza@sarawak.uitm.edu.my
}

Suriani Jack

Faculty of Information Management, Universiti Teknologi MARA Sarawak, Kota Samarahan Campus

Jalan Meranek, 94300 Kota Samarahan, Sarawak. Malaysia

Tel: 60-1988-8442Ｅ-mail: suejack@sarawak.uitm.edu.my

\author{
Zubaidah Bohari \\ Faculty of Computer Science and Mathematics, Universiti Teknologi MARA Sarawak \\ Kota Samarahan Campus \\ Jalan Meranek, 94300 Kota Samarahan, Sarawak. Malaysia \\ Tel: 60-198-586-836_E-mail : zbb4428@yahoo.com \\ Hj. Kamaruzaman Jusoff (Corresponding author) \\ Faculty of Forestry, Universiti Putra Malaysia, 43400 Serdang, Selangor. Malaysia \\ Tel: 60-389-467-176 E-mail: kamaruz@putra.upm.edu.my
}

Received: February 10, 2011 Accepted: February 28, 2011 doi:10.5539/ies.v4n2p153

\begin{abstract}
The role of Information and Communication Technology (ICT) in education has been peripheral, with new technologies being added to the traditional teacher centred model of instruction. Students in the global economy of the $21^{\text {st }}$ Century need to be creative thinkers and innovators. Thus, this paper provides an overview of the integration of innovation and education which plays an important role in propelling the human capital to a higher level to realize the objectives of Vision 2020. The integration of teaching and research is becoming a key issue in higher education, not only in order to differentiate the character of universities from other teaching and learning institutions, but also in order to find ways to create the kind of knowledge needed in a world characterized by a turbulent environment and increasing change in daily life.The right blend of pedagogies, tools and media needs to be created, quality assurance at various stages of planning, design and implementation should be embedded at every stage to ensure that we produce the desired graduates.
\end{abstract}

Keywords: Education, Innovation, Teaching, Learning, Research

\section{Introduction}

Learning is a continuous process. The students can thus slowly be made to understand this concept by adopting technology as there are fast changes in the field, and the newer concepts and innovations are continuously coming up. Education systems should contribute towards the development of creativity and creative problem solving (Osborn, 1992).

Students in the global economy of the $21^{\text {st }}$ Century need to be creative thinkers and innovators. Thus, the integration of innovation and education plays an important role in propelling the human capital to a higher level to realize the objectives of Vision 2020. In order to develop successful business systems and innovation acts as a driving force in the attempt to have sustainable development, in which problems usually cannot be solved by simple application of 
standard solution, but in actual fact need creativity. Besides the economic impact of innovation in terms of increasing the regional standard of living and providing further employment opportunities, we point out that the potential to generate innovation also exerts a tremendous influence on the social and ecological aspects of sustainable development. (Posh and Steiner, 2006)

\section{The Paradigm Shift in Higher Education}

Technology, globalization and competition have caused the ground shift under higher education worldwide, defying national borders and calling into question honoured traditions, myths, and previously unquestioned assumptions that can be called a changing paradigm in higher education (ACE, 2002). Nevertheless, over the last decade, we have seen marked and significant changes in our society. The terms "Global Village", "Bio-tehnological Society", "Post-Industrial Society", "Information Society" or "Information Age", and "Knowledge Society" are just a few of the terms that have been coined in an attempt to identify and understand the extent of these changes.

Inglis et al. (2002) saw the current period as dynamic with continuous change and transformation the juxtaposition of various images of social, economic and political life; and transformation of images such as Disneyworld, TV sports and Web pages into the realities in which we are involved. While there remains considerable debate as to the restructuring that is taking place, there is a widespread agreement that the production and distribution of knowledge is in significant processes in the determination of economic development and competitiveness (OECD, 2001). Educators are therefore expected to prepare their students for the outside world, while responding to the demands.

Undeniably, universities all over the world face an imperative to adapt and adjust to a whole series of profound changes. According to Ibrahim (2007), the focus in the year 2008 for UiTM is on Internalization. Programs, seminars and paper presentations that we conduct should not only carry local but international aspects including collaboration with overseas partners.

There is now far less dependence on the quality of an educator's subject knowledge. Instead, students follow work that interests and challenges them. In this learning environment, they are encouraged to show more initiative and the curriculum is less rigid. Educators are required to modify their teaching strategies to adapt to the new assumptions and change from a paper and pencil methodology to a student active learning environment. Students are increasingly expecting Higher Education to ingrate learning technologies to its operation.

\section{The Importance of Technology Innovation in Teaching and Learning}

At present, the multi-media technology, network technology and satellite transmission technology, as the representative of the information technology is developing very quickly. Modern educational technology based on information technology plays a significant role in promoting the modernization of education. Modern education technology will have a significant impact on ideas, forms, processes, methods, teachings and management of education. Application of modern education technology in continuing education will be a driving force to continuing education innovation. Using modern education theory and modern information technology in designing, developing, utilizing, evaluating and managing of the teaching process and then teaching resources will help to achieve the efficient development of continuing education (Long, et. al., 2008).

The effective use and management of the online discussion forum and learning becomes active and participative for the students. Based on the questions that are asked by the class after the lecture, the teacher can have a sense of the effectiveness of the teaching. When difficulties indicated by the questions being asked are recognized by the teacher, and then becomes a part of the next lecture, students recognizing its direct value to them will see the online forums as an important support tool in which their participation is also their benefit. For the teacher, it might indicate areas for course content revision or improvement (Tan, (2007).

In addition, an increasing number of traditional universities have begun to offer their programmes through Distance Education. (Virkus and Wood, 2004). Distance Education has the potential to generate new patterns of teaching and learning and there is evidence that it can lead to innovation in mainstream education, and may even have effects beyond the realm of education itself. It is also believed that Distance Education plays a particularly decisive role in the creation of the global knowledge-based society and will be an important element of future education and training system that have significant pedagogical, economic and organizational implications (UNESCO, 2002).

\section{The Integration of Network Technologies into Education System}

With the enrichment of Information technology, e-learning provides an alternative teaching and learning methodology. The role of information and communications technology in education has been peripheral, with new technologies being added to the traditional teacher centred model of instruction. Through the use of ICT students have developed a sense of independence and have learned to evaluate information sources at an earlier age. This generation relish the opportunity to research, routinely using the World Wide Web and enjoy extending their editing 
and presentation skills. However, the history of technological innovation in our profession suggests the adoption of a cautious stance. Successful exploitation will not just hen. It has to be carefully planned and organized. Some of the issues to be confronted are: the sustainability of the innovation; the effectiveness of self-managed learning over an extended period of time, the evaluation of pedagogic strategies; and the implications of new roles for educators. Creating a learning environment that will motivate learners is most important if we want to serve the needs of natives. Creativity is an important concept in modern learning situations. A host of activities can be promoted which involve learners in operating creatively and imaginatively. To the Internet generation of students, communication means email, online chats and Skype (Online Video). Their songs are not on CDs but in MP3 formats stored in music albums which are often times, stored in their hand phones, IPods or MP3 players. (Zoraini, 2007).

Based on a recent research in 2008 proposed by Suriani Jack from UiTM Sarawak on strategy to improve teaching and learning by using mind maps combined with multimedia learning application, it was discovered that most students are not satisfied with the conventional teaching method which is lacking in interactive and more on memorizing the theories in their reference books. Educators can be seen as innovators who navigates teaching and learning through innovations that could assists the students in dealing with some of their subjects in the university. An example of such innovation is the ABG (Accounting Balancing Game), innovated by Suzana Narawi and has been tested on students in UiTM Sarawak.

\section{Integrating More Drastic Innovation in Research and Teaching}

The integration of teaching and research is becoming a key issue in higher education, not only in order to differentiate the character of universities from other teaching and learning institutions, but also in order to find ways to create the kind of knowledge needed in a world characterized by a turbulent environment and increasing change in daily life (Posch and Steiner, 2006). However, UiTM still far behind in on-line teaching and learning, online forum, tele-conferencing, etc. According to Posch and Steiner (2006), they further emphasized that the role of innovators as 'navigators' and creative problem-solvers in business systems or any other regional system becomes crucial for the overall societal goal of sustainability, and therefore also for higher education and research. Hence, the integration of research and teaching can go a step further, by initiating intense interaction between academia and practitioners of the considered system. A new learning situation can be created where not only students, teachers and/or researchers can benefit, but practitioners as well. As such, UiTM always have mutual linkage and collaboration with industries to ensure the programs we are offering remains relevant in the global market.

The current quotation in business and academia seems to be: innovate or die! Drucker is not alone in telling us that continuing innovation is the "task and responsibility of the knowledge worker" (1999, p. 142). Academics are increasingly exhorting each other to embrace the creative imperative. Rationally, learning provides the conceptual link for integrating research and teaching: research can be seen as a process of learning for academics, teaching is a means of promoting students learning, successful innovation requires the life-long learning of all actors affected. The challenge is to create innovative institutional and organizational structures in research and teaching that lead to innovative solutions for future development through mutual learning process of all those concerned.

\section{Conclusion}

With the net generation of students with a new profile connecting to people and knowledge, and a paradigm of participation, many processes in the University is being redefined. Continuous learning and improvement are essential if we are to meet the demands of our various stakeholders and to stay competitive globally. Both educators and students have to engage as self-directed, life-long learners who actively seek and create opportunities to improve. On the other hand, learning has to be fun, stimulating, engaging and many more. The right blended learning which involved blended pedagogies with the combination of human interaction and computer interaction, tools and media needs to be created, quality assurance at various stages of planning, design and implementation should be embedded at every stage to ensure that we produce the desired graduates.

It is a challenge for educators to find innovative ways of enhancing students' learning in such a context. The University recognizes that carrying out a teaching innovation places exceptional demands on innovators and also on their departmental colleagues. When implementing new approaches, instructors take risks in terms of potentially negative evaluations from their students and peers, which may be perceived as damaging to their own professional recognition and advancement. At university level, the implementation of inter- and trans-disciplinary case studies is one effective way of breaking through existing conventional structures and processes. With this kind of case study, research and teaching activities can be integrated in a way that leads to a self-regulated mutual learning process between the actors concerned.

Last but not the least, teaching is a means of promoting student learning, and successful innovation requires the life-long learning of all actors affected. The challenge is to create innovative institutional and organizational 
structures in research and teaching that bring to innovative solutions or future development through the mutual learning process of all those concerned. "The magic is in the mix, the beauty is in the blend"(E-learning Centre, UK 2008).

\section{References}

ACE. (2002), The Brave New (and Smaller) World of Higher Education: A Transatlantic View, European University Association, American Council on Education, Washington, DC, [Online] Available: www.acenet.edu/bookstore .

Alexander, B. (2006). Web 2.0: A new wave of innovation for teaching and learning? Educause Review, 41 (2), $32-44$

Conole, G. de Laat, M., Dillon, T. And Darby, J. (2008). 'Discuptive technologies', 'pedagogical innovation': Waht's ne? FIndingd from an in-depth study of students' use and perception of technology. Computers\&Education, 50, 511-524.

Drucker. (1999), A New Paradigm of Knowledge Production in Higher Education.

Ibrahim Abu Shah. (2007). Vice Cansellor. Personal Interview. Shah Alam, Malaysia.

Inglis, A., Ling, P. and Joosten, V. (2002). Delivering Digitally: Managing the Transition to the Knowledge Media,2nd ed., Kogan Page, London.

Long, Zhaohui, L., Gengsheng, L. and Xiaoqin Y. W. (2008). Modern Education Technology with Creativity of Continuing Education. [Online] Available: http://smartech.gatech.edu/dspace/handle/1853/24421

OECD. (2001). Cities and Regions in the New Learning Economy, OECD, Paris.

Osborn, A. (1992). The creative trend in education, in Parnes, S.J. (Eds),Source Book for Creative Problem Solving, Creative Education Foundation Press, New York, NY, pp.39-62

Posch, A. and Steiner, G. (2006). Integrating Research and Teaching on Innovaton for Sustainable Development, International Journal of Sustainability in Higher Education, 7. Retrieved December 23, 2008, from the Proquest database.

Roberts, G. (2004). The new covert curriculum: a critical actor-network approach to learning technology policy. In Proceedings of the fourth international conference on networked learning, Lancaster University and the University of Sheffield.

Tan, Daniel. Assoc. Prof. (2007) Learning that Clicks: Helping Learners Learn Better. International Conference of E-learning. Shah Alam.

UNESCO. (2002), Open and Distance Learning: Trends, Policy and Strategy Considerations, UNESCO, Paris. Virkus, S. and Wood, L.(2004) Change and Innovation in European LIS Education, Ne Library World. 17.

Zoraini Wati Abas. (2007) Strategies to Create A Motivating Learning Environment. International Conference of E-learning. Shah Alam. 